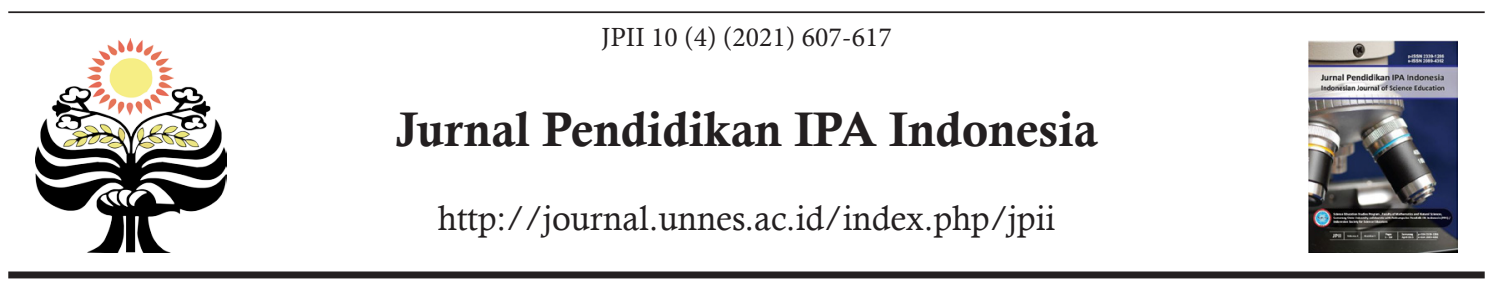

\title{
ANALYSIS OF THE ROLE OF ANDROID-BASED LEARNING MEDIA IN LEARNING CRITICAL THINKING SKILLS AND SCIENTIFIC ATTITUDE
}

\author{
W. Isnaeni*1, Y. A. Sujatmiko ${ }^{2}$, P. Pujiasih ${ }^{3}$ \\ 1,2,3 Universitas Negeri Semarang, Indonesia
}

DOI: $10.15294 /$ jpii.v10i4.27597

Accepted: December $7^{\text {th }} 2020$. Approved: December $27^{\text {th }} 2021$. Published: December $31^{\text {st }} 2021$

\begin{abstract}
This study aims to analyze and describe android-based learning media's role in teaching students critical thinking skills and scientific attitudes. The learning media are Androwebic (android-based webcomic) and E-Bokartumban (e-book on plant diversity in Banjarnegara), developed previously. This research is a qualitative descriptive study involving 301 students, six biology teachers and six high school students. The data collected includes critical thinking skills, analytical skills, scientific attitudes, environmental care attitudes, media components supporting student competence, and teacher and student responses. Data on critical thinking and analytical skills were measured using tests and non-tests. Other data were measured using non-test instruments, including interview guides, scientific attitude observation sheets, students' environmental care attitudes, media component observation sheets, and student and teacher questionnaires. Quantitative data on critical thinking and analytical skills were analyzed using the n-gain test, while other data were descriptively analyzed. The research results showed that the E-Bokartumban and Androwebic components support students' critical thinking skills, analytical skills, and environmental care attitudes. Androwebic can train students' analytical thinking skills and scientific attitude. The two media developed were considered very helpful in the learning process. The study concluded that Android-based media in Androwebic and E-Bokartumban have a vital role in training critical thinking skills, analytical skills, scientific attitudes, and environmental care attitudes.
\end{abstract}

(C) 2021 Science Education Study Program FMIPA UNNES Semarang

Keywords: androwebic; e-bokartumban; critical thinking skills; scientific attitude

\section{INTRODUCTION}

Biology learning involves skills and reasoning (Eshun \& Amoah, 2018). In developing reasoning power and skills, learning that can emphasize aspects of application, analysis, synthesis, and evaluation, not only emphasizing aspects of understanding and knowledge, is needed. For this reason, a learning process that can improve cognitive, affective, psychomotor competencies and learning methods that can motivate students to be creative, confident, and think critically are needed to assess information (Pujiasih et al., 2021). Critical thinking skills are needed to explain and

*Correspondence Address

E-mail: wiwiisna@mail.unnes.ac.id solve problems (Thomas, 2011). Teaching critical thinking and problem-solving skills can be done with problem-based learning/PBL (Yew \& Goh, 2016). PBL is a strategy to develop knowledge and problem-solving skills (Chung, 2019).

Students' development of critical thinking skills must focus on activities to teach content (knowledge) and methods or ways to find the process and evaluate information (Nhat et al., 2018). Students can think critically in learning, but this skill sometimes does not develop well. Therefore, it is necessary to use a method to develop students' critical thinking skills. One of the teaching methods considered appropriate is teaching using android-based media. The learning media in this study are androwebic (android-based webcomic) 
and e-bokartumban (e-book of plant diversity in Banjarnegara), developed previously. Androwebic has proven effective for teaching analytical skills and scientific attitudes (Sujatmiko et al., 2021). E-bokartumban also effectively improves critical thinking skills and environmental care attitudes (Pujiasih et al., 2021). However, neither Sujatmiko nor Pujiasih explained the role of the two android-based media in improving students' competencies and attitudes. This study's urgency, novelty, and purpose are to analyze or describe the role of androwebic and e-bokartumban in teaching students' skills and attitudes. These skills and attitudes include critical thinking skills, analytical skills, scientific attitude, and environmental care attitude in students. The status of this research is to support previous research by Sujatmiko et al. (2021) and Pujiasih et al. (2021).

Mutakinati et al. (2018) stated that students with critical thinking skills easily analyze, evaluate, and connect with evidence or arguments before deciding or assessing information. Students' critical thinking skills play an important role in achieving learning achievement, formal reasoning, and creativity (Puspita et al., 2017; Purnami et al., 2021). Learning that facilitates critical thinking skills can be realized if all parties, from policymakers to teacher universities, local education departments, schools, and families, cooperate and participate (Nhat et al., 2018). The research results of Seventika et al. (2018) show that most $(>55 \%)$ of 11 th-grade students of vocational schools in Indramayu have a low level of critical thinking skills.

Textbooks and modules with few pictures still dominate biology learning in schools, and learning is still teacher-centred. This situation causes students' mindsets to be limited, and students' understanding of biology concepts weakens so that students' critical thinking skills and scientific attitudes are still weak. The results of interviews with several state high school/MA teachers in Banjarnegara and Jepara reinforce this statement. Information obtained from the results of the interview, among others: (1) Learning has not utilized student-centered media to its full potential; (2) students are allowed to bring smartphones, but they have not been appropriately used; (3) technology (smartphone) as a tool or media that does not support learning; (4) limited learning time. Based on the interview with teachers, it can be concluded that these problems can be minimized by utilizing the technology owned by students and student-centered learning strategies to the fullest. The circulatory system and biodiversity are examples of biology learning materials that must be taught using media. The material on the circulatory system needs to be taught with the media because it contains complex concepts to be presented more interestingly. Biodiversity material, especially plant diversity, also needs to be taught by optimizing electronic media to present a plant diversity environment in the classroom.

The availability of learning media will facilitate interaction between teachers and students so that learning activities will be more effective and efficient (Puspitasari et al., 2018). The existence of learning media facilitates ease of learning, fosters interest in learning, and makes it easier for students to learn independently so that the learning process will be more effective (Surjanti et al., 2018). The use of android-based media can make students more interested in learning. The use of pictorial technology media also attracts students' attention more than textbooks. Taking this into account, it is clear that optimizing the use of modern technology-based media in learning is an urgent matter, especially during the current pandemic. In learning during the $\mathrm{CO}$ VID-19 pandemic, the use of media and technology must make a real contribution to knowledge and the emergence of educational practices with online and digital education formats (Williamson et al., 2020). Based on the problem, optimizing learning media is helpful for appropriately visualizing learning materials. The media should have a simple structure that focuses on one goal. Learning media that are expected to be useful or good to overcome the learning problems mentioned earlier should be easy to carry and use anywhere. Sukenda et al. (2019) stated that multimedia-based learning media should be packaged into software to present material.

One of the important learning media packaged into software is the environment. The environment is useful for equipping students with a conscious mind and care for the environment and its issues (Amini, 2015). The environment is also essential to instill knowledge, skills, attitudes, behavior, motivation, commitment to solving environmental problems, and environmental care attitude. The results of Putri \& Prodjosantoso's research (2020) prove that science comics media (guided inquiry-based science comics) can improve critical thinking skills and scientific attitudes. A scientific attitude is an attitude that encourages students to solve problems (Hasanah et al., 2020). Khasanah et al. (2017) stated that the module based on critical thinking skills on respiratory system material helps practice critical thinking skills. 
Based on the description above, media is essential in learning to instill skills and attitudes in students. One of these media is android-based media, as software. In this study, the role of android-based media was analyzed in teaching or training attitudes and skills to students. There are two android-based media: 1) E-bokartumban, an e-booklet about plant diversity in Banjarnegara, 2) Androwebic, an android-based webcomic about the circulatory system. From previous studies by Sujatmiko et al. (2021) and Pujiasih et al. (2021), both media are useful for improving critical thinking skills, analytical skills, scientific attitudes, and environmental care attitudes in students.

Some questions need to be answered in this research: 1) Does androwebic play a role in teaching students' analytical skills and scientific attitudes?; 2) Does the e-bokartumban play a role in teaching students critical thinking skills and environmental care attitudes?; 3) How does the androwebic function in teaching students analytical skills and scientific attitudes?; 4) How does the e-bokartumban function in teaching students critical thinking skills and environmental care?; 5) What learning activities do students do while learning using the two android-based media?; 6) How do students and teachers respond to both media?

\section{METHODS}

This study aims to analyze (and describe) the role of android-based learning media in teaching or training critical thinking skills, analytical skills, scientific attitudes, and environmental care attitudes. Therefore, the research design used is descriptive qualitative (Sugiyono, 2015). The samples (subjects) were six biology teachers, 196 10th-grade students from three high schools in Banjarnegara, and 105 11th-grade students from three high schools in Jepara. The research sample was selected using the purposive sampling technique. This study used the technique because it requires research subjects relevant to the determined characteristics.

The data collected includes critical thinking skills, analytical skills, scientific attitudes, environmental care attitudes, media components supporting student competence, student learning activities, and teacher and student responses. Data were collected in several ways: tests, observations, questionnaires, and documentation. Data on critical thinking and analytical skills were measured using a test instrument, while other data were measured using a non-test instrument. The test instrument used contains multiple- choice questions with five choices. The non-test instruments include interview guides, scientific attitude observation sheets, student environmental care attitudes, media component observation sheets, learning activity observation sheets, and student and teacher questionnaires.

Quantitative data on critical thinking skills and analytical skills were analyzed using the ngain test, while other data were analyzed descriptively qualitatively. Descriptive qualitative data analysis was carried out in 4 stages: data collection, data reduction, data presentation, and concluding (Rohmadi \& Nasucha, 2015). The data that has been collected is collected according to their respective categories, including test result data, questionnaire results and observation data. The data is then reduced to obtain data that focuses on research problems: to analyze and describe the role of androwebic and e-bokartumban media in teaching the chosen skills and attitudes. The data obtained are presented in tabular or narrative form, depending on the characteristics of each data. The last stage is concluding based on the available data.

\section{RESULTS AND DISCUSSION}

In the following, the androwebic and ebokartumban media are presented which were studied in this study. Media Androwebic have a general picture as shown in Figures 1.

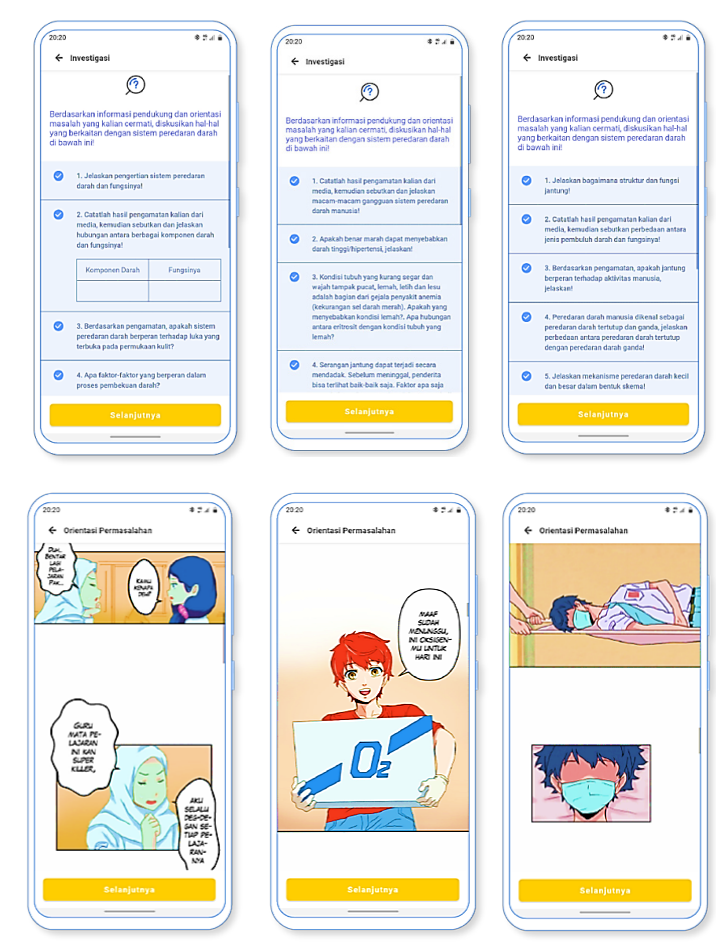

Figure 1. Androwebic Media Display 
Figure 1 shows the android component of the media, which contains 3 discussion activities. In each discussion activity, various questions and appropriate pictures are presented. The comics are designed in such a way, to attract students' attention and interest in learning. Another learning media is e-bokartumban, which can be illustrated by Figures 2 and 3.

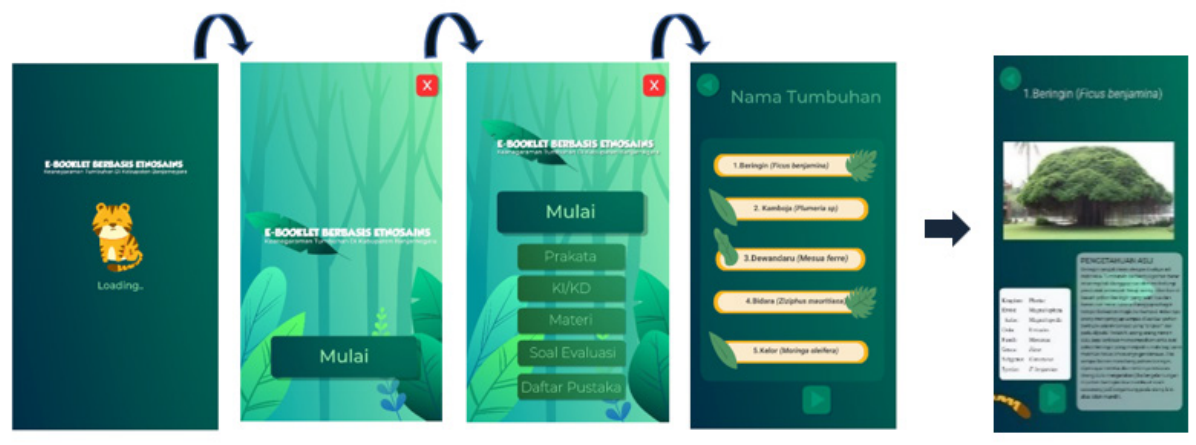

Figure 2. Examples of E-bokartumban Media Components at the Beginning Section

Figure 2 presents the media display at the beginning of the media, showing the various menus available on the media. At the beginning of the e-bokartumban media, information about the contents of the media, including the student competencies that are expected to be achieved, is informed. At the beginning of this media also informed about the content of the material (con- tent), assessment and bibliography. On the far right of Figure 2, an example of how material is displayed in the media is presented. An example of the presentation/display of material in the media is presented in Figure 3. An example of the presentation of material in the media is also presented in Figure 3.
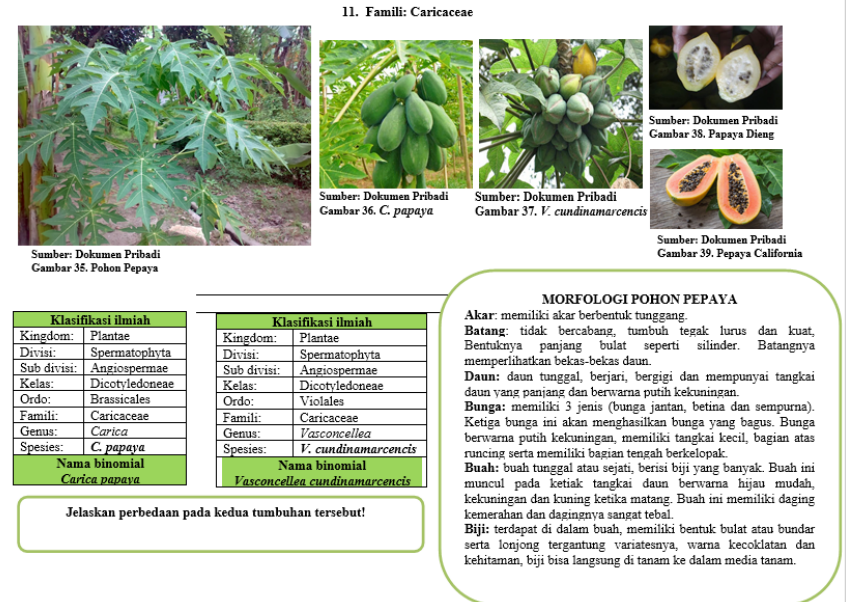

Figure 3. Examples of E-bokartumban Media Components at the Material Section

In Figure 3, you can see the display of the contents of the material, containing colorful pictures of the leaves and fruits of the Caricaceae family, as well as their description and classification, as well as appropriate questions. The display of the material content on the e-bokartumban media as shown in Figure 3 is useful for visuali- zing the original object of study that exists in the real world and bringing it to students, so that students can observe it more concretely.

Students' analytical skills in learning using Androwebic were obtained from the pretest and posttest results (presented in Table 1).

Table 1. Students' Pretest and Posttest Scores in Biology Learning Using Androwebic

\begin{tabular}{ccc}
\hline Information & Pretest Score $(\mathbf{n = 1 0 5})$ & Posttest Score $(\mathbf{n = 1 0 5})$ \\
\hline Highest score & 93.33 & 100 \\
Lowest score & 13.33 & 60 \\
Average value & 53.65 & 88.83 \\
\hline
\end{tabular}


Table 1 shows the score of posttest is higher than pretest. The pretest showed an average score of 53.65 (not yet reached 75 as KKM), while the posttest score achieved by students was an average of 88.83 (beyond the KKM). KKM is the minimum mastery criteria. KKM is a reference for educators in assessing students' competence in the subjects.

The increase in students' analytical thinking skills was obtained from the results of the n-gain test on the students' pretest and posttest scores (in Table 1). The results of the n-gain test showed that students who achieved high, medium and low analytical skills were $72 \%, 24 \%$ and $4 \%$, respectively. From these results, the androwebic effectively improves students' analytical skills, especially in learning material about the circulation system. From these results, it can be stated that androwebic media has an important role to teach students' analytical skills.

This happens because androwebic media has various menus/component which play an important role in teaching these abilities; this media also plays an important role in teaching scientific attitudes, as presented in Table 2.

Table 2. Androwebic Component that Support Analytical Thinking Skills (A) and Scientific Attitude (B)

\begin{tabular}{cll}
\hline No & $\begin{array}{c}\text { Indicators of Analytical } \\
\text { Thinking Skills }\end{array}$ & \multicolumn{1}{c}{ Media Components } \\
\hline A & Analytical Thinking Skills & \\
\hline 1 & Differentiating & Task to differentiate in group discussion questions \\
2 & Organizing & Task for grouping on group discussion questions \\
3 & Connecting & The task concludes with group discussion questions \\
\hline B & Scientific Attitude & \\
\hline 1 & Curiosity & Task to observe on the webcomic \\
2 & Respect for data/facts & Group discussion task in the media investigation section \\
3 & Flexibility in thinking & Group discussion task in the media investigation section \\
4 & Open minded and cooperate & Group discussion task in the media investigation section \\
5 & Perseverance & The task of presenting the observations to be presented \\
\hline
\end{tabular}

From Table 2, information is obtained that androwebic media has 3 components to teach analytical thinking skills (points A1-A3) and 5 components to instill scientific attitudes (points B1-B5). These eight components facilitate students to be skilled in analytical thinking and have a scientific attitudes. Information about students' scientific attitudes in learning using Androwebic media was obtained from observing students' scientific attitudes using observation sheets. Androwebic was created specifically so that it has several good facilities to practice six aspects of scientific attitude (see Table 3). Students' scientific attitude was observed using student activities during the learning process using androwebic media, presented in Table 3.

Table 3. Students' Scientific Attitudes During the Learning Process Using Androwebic Media

\begin{tabular}{lcccc}
\hline \multicolumn{1}{c}{ Indicator } & $\boldsymbol{\Sigma}$ Score & Max Score & Score (\%) & Criteria*) \\
\hline Pay attention to every new thing & 1086 & 1260 & 86.19 & Very good \\
$\begin{array}{l}\text { Appreciate and conclude according to facts } \\
\text { Not always feel right, change opinion after con- }\end{array}$ & 1056 & 1260 & 83.81 & Very good \\
$\begin{array}{l}\text { sidering the evidence } \\
\text { Ask questions and give opinions }\end{array}$ & 1124 & 1260 & 89.21 & Very good \\
$\begin{array}{l}\text { Participate in groups } \\
\text { Record complete observations }\end{array}$ & 1107 & 1260 & 87.86 & Very good \\
*): Sugiyono (2015): very good: 81-100; good: 61-80; 41-60: enough/currently & & & \\
\end{tabular}

*): Sugiyono (2015): very good: 81-100; good: 61-80; 41-60: enough/currently 
In Table 3, it can be seen that the average of students' scientific attitude is in the very good category. This very good category is determined based on the criteria from Sugiyono (2015).

Android-based e-bokartumban media contains information about the diversity of plants in Banjarnegara. The information in question includes the scientific classification of each type of plant and a description of its morphology, a dissertation with attractive colored pictures. The e-bokartumban is useful for presenting the natural environment to the classroom with its characteristics. The e-bokartumban as a smart phone application makes it very easy for students to use it. The results of the n-gain test showed that after learning to use e-bokartumban, students experienced an increase in critical thinking skills. The increase in students' critical thinking skills (n-gain) was 0.69 in the medium category (tend to be high). Students who achieve high, medium and low critical thinking skills are $53 \%, 45 \%$ and $2 \%$, respectively. From these results, it can be stated that e-bokartumban has an important role to improve critical thinking skills. This role is supported by the characteristics of the e-bokartumban, which has a useful supporting component to facilitate the emergence of critical thinking skills (see Table 4).

Table 4. Indicators of Students' Critical Thinking Skills and E-bokartumban Components that Play a Role in Facilitating These Skills

\begin{tabular}{cll}
\hline No. & Indicators of Critical Thinking Skills & \multicolumn{1}{c}{ Media Components } \\
\hline 1 & Give a simple explanation & Evaluation questions, students discussion sheets \\
2 & Build basic skills & Evaluation questions, students discussion sheets \\
3 & Conclude & Evaluation questions, students discussion sheets \\
4 & Identify terms and consider a definition & Evaluation questions, students discussion sheets \\
5 & Set strategy and tactics & Evaluation questions, students discussion sheets \\
\hline
\end{tabular}

The data in Table 4 informs that students using e-bokartumban media practice to make simple statements, build basic skills, conclude, and so on, through various components of ebokartumban media, namely in the evaluation/

assessment section and through several discussion activities provided. E-bokartumban also has various components that play an important role in growing various indicators of environmental care attitudes (see Table 5).

Table 5. Competency Indicators of Environmental Care Attitudes in Students and Components of the E-bokartumban Media that Facilitate the Emergence of These Attitude Indicators

\begin{tabular}{cll}
\hline No & \multicolumn{1}{c}{ Aspects and Indicators of Environmental Care Attitude } & \multicolumn{1}{c}{ Media Components ${ }^{*}$ ) } \\
\hline 1 & $\begin{array}{l}\text { Have thought that plants and animals have rights were equal } \\
\text { to humans }\end{array}$ & Introduction to the materials \\
2 & $\begin{array}{l}\text { Have feelings/emotions about human actions that cause } \\
\text { disaster }\end{array}$ & Introduction to the materials \\
3 & $\begin{array}{l}\text { Have thought that the environment is very fragile and easily } \\
\text { disturbed balance }\end{array}$ & $\begin{array}{l}\text { Student discussion sheets, } \\
\text { materials }\end{array}$ \\
4 & $\begin{array}{l}\text { Have feelings and tendencies of behavior that the tendency of } \\
\text { human beings there is a limit in controlling nature }\end{array}$ & $\begin{array}{l}\text { Student discussion sheets, } \\
\text { materials }\end{array}$ \\
5 & $\begin{array}{l}\text { Tend to take advantage of the source power of nature that } \\
\text { has been used }\end{array}$ & $\begin{array}{l}\text { Student discussion sheets, } \\
\text { materials }\end{array}$ \\
6 & $\begin{array}{l}\text { Tend not to be arbitrary towards the environment } \\
7\end{array}$ & $\begin{array}{l}\text { Student discussion sheets, } \\
\text { materials }\end{array}$ \\
8 & $\begin{array}{l}\text { Have emotional feelings about actions that can cause environ- } \\
\text { mental damage }\end{array}$ & $\begin{array}{l}\text { Student discussion sheets, } \\
\text { materials } \\
\text { materials }\end{array}$ \\
*): The examples of the components of the e-bokartumban media are presented in Figures 2 and 3
\end{tabular}


In Table 5, column 3, various sections of the media are presented that are useful for strengthening various indicators of environmental care attitudes (column 2 of Table 5). The various components of the e-bokartumban media are very useful to familiarize students with various attitudes that lead to the formation of environmental care attitudes in students. The compo- nents of the e-bokartumban media in question are the material components and student worksheets. Students' responses to learning using androwebic were obtained from questionnaires given at the end of the lesson. Information about students' positive responses to androwebic media is presented in Table 6.

Table 6. Student's Positive Response to Androwebic Media

\begin{tabular}{lcccc}
\hline Indicators of Androwebic Media & Score & Max. Score & Percentage (\%) & Criteria*) \\
\hline Affective consideration & 755 & 840 & 89.88 & Very good \\
Learning & 1116 & 1260 & 88.57 & Very good \\
Multimedia display & 2308 & 2520 & 91.59 & Very good \\
Navigation & 1487 & 1680 & 88.51 & Very good \\
Robustness & 1507 & 1680 & 89.40 & Very good \\
Average & & & 89.59 & Very good \\
*): Sugiyo
\end{tabular}

*): Sugiyono (2015): very good: 81-100; good: 61-80; 41-60: enough/currently

Table 6 shows that students give positive responses to andowebic media with very good category. Positive responses to androweb media were also obtained from teachers, through ques- tionnaires. The positive responses of teachers to androwebic media with a very good category are presented in Table 7.

Table 7. Teachers' Positive Response to Androwebic Media

\begin{tabular}{lcccc}
\hline Indicators of Androwebic Media & Score & Max. Score & Percentage (\%) & Criteria*) \\
\hline Affective consideration & 22 & 24 & 91.67 & Very good \\
Learning & 30 & 36 & 83.33 & Very good \\
Multimedia display & 64 & 72 & 88.89 & Very good \\
Navigation & 41 & 48 & 85.42 & Very good \\
Robustness & 42 & 48 & 87.50 & Very good \\
& & & 87.36 & Very good \\
\hline *): Sugiye
\end{tabular}

*): Sugiyono (2015): very good: 81-100; good: 61-80; 41-60: enough/currently

From the results in Tables 6 and 7 it can be stated that androwebic media received a very good response from students and teachers. This means that androwebic media a) attracts and motivates students/users (affective considerate), b) the material is appropriate to students and can make students interact with the media (learning), c) the media display (multimedia display) is good, d) navigation good media, and 5) this media is sturdy (resistant) to use, easy to access and the menu is easy to choose (robustness).

The problems in the discussion menu are related to daily events. For example, the work of the heart, normal and non-normal blood conditions and blood type. Those are all everyday things that students often experience. The availability of various menus on androwebic stimulates students' curiosity and encourages students to practice problem-solving (see Figure 1 and Table 2). Both activities require analytical thinking skills so that students' skills are well trained. This statement is under the research of Prawita et al. (2019) and Sari et al. (2019), which states that the use of learning media that presents problems can improve students' learning outcomes and analytical thinking skills.

Comics help students learn by simplifying science concepts and making them easier to remember (Ozdemir, 2017). Comics also contribute to arousing students' enjoyment of science and the perception of success in science. Demirci \& Zyürek (2017) state that the cartoon concept can effectively develop critical thinking skills. Colorful cartoons attract attention and encourage students' active participation in learning activities (think more actively). Indirectly, it plays an important role in helping to develop critical thinking skills. An active learning process is also very useful for improving students' critical thinking skills (Styers et al., 2018) 
During the discussion stage in biology learning using Androwebic, students are trained to discuss and exchange ideas about problem solutions systematically and logically (Figure 1). Thus, students become trained to think analytically. Sari et al. (2019) proved that learning by actively involving students to solve problems improved analytical thinking skills and learning outcomes. Analytical thinking skills is one component of critical thinking skills (Facione 2015).

The teacher said that the androwebic media based on problem-based learning was very good, easy to use, up to date. The material presented was equipped with attractive visuals, ready to use anytime and anywhere with Android devices. Sung et al. (2016) stated that using android devices (smartphones) in learning was better and more effective than conventional learning.

In this study, comics are used to teach material about the circulation system, which is very complex and cannot be observed directly. The choice of comics to be used in Androwebic turned out to be very appropriate because it got an outstanding response from students and teachers (see Tables 6 and 7). This statement is in accordance with the statement of Morel et al. (2019), that comics are an excellent tool to help educators teach complex subjects and explain the occult world. Based on the above description, it can be stated that Androwebic media has an important role to train critical thinking skills.

In Table 3 it is presented that the average scientific attitude of students is in the very good category. It happened because, since the beginning of the learning using Androwebic, students are always motivated to learn and seek information independently. During the learning process assisted by androwebic media, students show a more caring attitude, respect, and conclude according to facts. During the learning process, students are also accustomed not to always feel right, dare to ask questions, dare to express opinions, be active in groups, and record complete observations. Students must solve discussion questions that contain contextual problems in the learning process. Every activity carried out during the discussion process positively contributed to scientific attitudes. This is what can encourage students to think analytically in solving problems. This is under the statement of Dwianto et al. (2017) that the application of learning media that presents contextual problems through discussion can positively contribute to students' formation of scientific attitudes.

Table 4 shows that the e-bokartumban media has components that facilitate each indicator of critical thinking competence in this study. There are five stages of critical thinking with each indicator: 1) providing simple explanations, 2) building basic skills, 3) concluding, 4) identifying terms, 5) considering a definition, setting strategies and tactics (Kartimi \& Liliasari, 2012). These thinking indicators can be measured when students work on discussion sheets and evaluation questions on the media. Wiguna et al. (2019) and Damopolil \& Kurniadi (2019) explained that students' learning outcomes increase after using android-based media. Based on the description above, it can be emphasized that the e-bokartumban has an important role in teaching or practicing critical thinking skills. Arista \& Kuswanto (2018) stated that smartphones' media increases enthusiasm, interest, and motivation in learning activities. All of these things can increase students' independence and understanding of concepts.

From Table 5, indicators of environmental care attitudes use a scale adapted from NEPS. Indicators of the environmental care attitude are as follow: 1) Having the idea that plants and animals have the same rights as humans, 2) having feelings/emotions about human actions that cause disasters, 3) having the thought that the environment is very vulnerable and its balance is easily disturbed, 4) having feelings and behavioral tendencies that human tendencies have limits in controlling nature, 5) having behavioral tendencies to take advantage of used natural resources, 6) has a behavioral tendency not to be arbitrary towards the environment, 7) has thoughts and is interested in environmental issues, and 8) has emotional feelings towards actions that can cause environmental damage. All indicators of environmental care attitudes can be measured as long as students use the media when reading the material and during group discussions during the learning process.

Learning Biology (on plant diversity material) with e-bokartumban media makes a positive contribution to increasing students' environmental care attitudes. Environmental care attitudes are attitudes and actions that always try to prevent damage to the surrounding natural environment and develop efforts to repair natural damage (Yaumi, 2014). Environmental care attitudes can be shown by attitudes and actions that always try to prevent environmental damage and repair the natural damage (Mardikaningtyas et al., 2016).

Based on the description in the paragraph above, it can be stated that the use of androidbased learning media is very effective in increasing student understanding. This statement follows the opinion of Sudarsana et al. (2019), which 
states that the use of technology-based learning media can improve student learning outcomes. Junaedi et al. (2018) and Damopolil \& Kurniadi (2019) found that applying android-based media can improve student learning outcomes. Learning that uses technology can increase student interest and learning outcomes (Sudarsana et al., 2019).

Positive response of students to the androwebic media used in biology learning were obtained from questionnaires given at the end of the lesson. Information about students' positive responses to Androwebic media is presented in Table 6. Table 6 shows the average score for each indicator that shows very good criteria. In some indicators, the student response rate shows the maximum score. Students are interested and motivated to learn with comics on the media. Besides being interested and motivated by comics, students also acknowledged that the material equipped with pictures on Androwebic media was beneficial and made it easier for students to learn because it had been summarized in a structured way. The problems in the Androwebic media also increase students' activeness in problembased learning activities. In the learning process, students not only listen but also try, discover, and conclude. Therefore, students' understanding, analytical thinking ability, and scientific attitude will be higher.

In terms of appearance, Androwebic media received high points in very good criteria, showing that students are very interested in the appearance of Androwebic media. Androwebic media with pictures on every material detail provides the proper visualization. It makes it easier for students to understand abstract blood circulation material. Androwebic media also help students understand and discover concepts about the circulatory system. Appropriate learning media and students' character in learning can help students find concepts contextually. The media in question must be engaging, contain extensive learning resources, contain information whose presentation is accompanied by visual images. The use of a problem-based learning approach that is complemented by the use of learning media has been proven to be able to foster student interest and motivation to be more active in learning to create fun learning, understanding the material of the circulatory system will increase (Lee et al., 2015; Maulana \& Sulistyoningrum, 2018). From the data in Table 7 , it is known that the average score for each indicators is $87.36 \%$, with a very good category. The teacher said that androwebic media is very good, easy to use, and up-to-date. The material in these media is equipped with attractive visuals. It can be used anytime and anywhere on android devices. It is confirmed by Sung et al. (2016), which states that android devices such as smartphones are better and more effective than conventional learning. Students are more enthusiastic because the learning process is student-centered, while the teacher only directs and guides. This statement is under the findings of Ali (2019), which proves that student-centered learning will improve students' skills to understand the material and problem-solving skills. In such circumstances, the teacher directs and guides as necessary.

The responses of students and teachers in this section were obtained from the questionnaire, described by ten indicators. The descriptive data analysis on responses to e-bokartumban media shows that students and teachers each gave a response of $89.13 \%$ and $90.09 \%$ (very good category). The teachers stated that the e-bokartumban helped students build the concept of biodiversity. The teachers also positively responded to student activities in learning because it made students very enthusiastic during discussion. The teacher said that the E-Bokartumban media is an attractive, contemporary, easy to use, easy to carry media, and the material presented is evident. Thus, it can be emphasized that the e-bokartumban media is a perfect medium to use in learning and has excellent potential to train critical thinking skills and environmental care attitudes, as previously stated.

The description clearly states that Androwebic media can train students' analytical thinking skills by $92.68 \%$ and scientific attitude by $85.66 \%$. Students and teachers positively responded to the android-based media. E-bokartumban also trains critical thinking skills and environmental care attitudes. E-Bokartumban is also responded positively by students and teachers by $89.13 \%$ and $90.09 \%$, respectively. Thus, it can be stated that the androwebic and e-bokartumban analyzed in this study responded well by students and teachers and played an essential role in teaching skills and attitudes. This media has a vital role in teaching students' analytical skills, critical thinking skills and scientific attitudes, and environmental care attitude in learning biology. 


\section{CONCLUSION}

From the discussion above, the following conclusions can be drawn. E-Bokartumban media shows an essential role in teaching students critical thinking skills and environmental care attitudes. Androwebic media shows a vital role in teaching students' analytical skills and scientific attitudes. The level of critical thinking skills, analytical skills, scientific attitudes, and environmental care attitudes of students after learning to use android-based media increased to good and very good. E-Bokartumban can teach students critical thinking skills and environmental care attitudes because it contains various components that can facilitate activities that are indicators of critical thinking skills and environmental care attitudes. Androwebic can used to teach analytical skills and scientific attitudes to students. It contains various components that can facilitate activities that are indicators because they contain various components that can facilitate activities that are indicators of analytical skills and scientific attitudes. The learning activities carried out by students while learning to use the two androidbased media include various activities that match the indicators of critical thinking skills, analytical skills, scientific attitudes, and environmental care attitudes. Students and teachers showed an excellent response to Androwebic and e-Bokartumban in Biology learning. Two types of Android-based media (Androwebic and e-bokartumban) in Biology learning have proven to have a vital role in teaching students critical thinking skills, analytical skills, scientific attitudes, and environmental care attitudes.

\section{ACKNOWLEDGEMENTS}

The authors would like to thank Prof. Dr. Enni Suwarsi Rahayu, M.Si., and Prof. Dr. Retno Sri Iswari, S.U., as the material expert validator, Dr. Budi Naini Mindiyarto, M.App.Sc., and Mohammad Fikri, S.Sn (Pusdatin Kemendikbud) as media expert validators. The latter have provided beneficial suggestions for improving this research. The authors also would like to thank Dr. Sigit Saptono, M.Pd (Coordinator of S2 Science Education study program) and Dr. Saiful Ridlo, M. Si. This research was supported by the Lembaga Penelitian dan Pengabdian Masyarakat Universitas Negeri Semarang, which has funded this research (the contract number of the funding letter: SP DIPA-023.17.2.677507/2020, 27-12-2019, following the Letter of Assignment of Research Implementation of UNNES DIPA Funds Year 2020, Number 166.23.4/UN37/ PPK.3.1/2020, 23-04-2020.

\section{REFERENCES}

Ali, S. S. (2019). Problem based learning: a studentcentered approach. English Language Teching, 12(5), 73-78.

Amini, R. (2015). Outdoor Based Environmental Education Learning and its Effect in Caring Attitude Toward Environment. Journal Pendidikan IPA Indonesia, 4(1), 43-47.

Arista, F. S., \& Kuswanto, H. (2018). Virtual physics laboratory application based on the android smartphone to improve learning independence and conceptual understanding. International Journal of Instruction, 11(1), 1-16.

Chung E. Y. (2019). Facilitating learning of community-based rehabilitation through problem-based learning in higher education. BMC medical education, 19 (1), 433.

Damopolil, I., \& Kurniadi, B. (2019). The development of android-based mobile learning supported by problem-based learning strategy for students' learning success. International Journal of Scientific and Technology research, 8(7), 190-193.

Demirci, F. \& Özyürek, C. (2017). The Effects of Using Concept Cartoons in Astronomy Subjects on Critical Thinking Skills among Seventh Grade Student. International Electronic Journal of Elementary Education, 10(2), 243-254.

Dwianto, A., Wilujeng, I., Prasetyo, Z. K., \& Suryadarma, I. G. P. (2017). The development of science domain based learning tool which is integrated with local wisdom to improve science process skill and scientific attitude. Jurnal Pendidikan IPA Indonesia, 6(1), 23-31.

Eshun, E., \& Amoah, C. A. (2018). Assessing the reasoning skills of biology students in selected senior high schools in the central region of Ghana. International Journal of Scientific Research and Management (IJSRM), 6(04).

Facione, P. A. (2015). Critical thinking: What it is and why it counts. Insight assessment, 2007(1), 1-23.

Hasanah, S. I., Mustofa, R. F., \& Ardiansyah, R. (2020). Correlation between Generic Science Skills and Scientific Attitudes on Learning Outcomes. BIOEDUSCIENCE, 4(2), 124-128.

Junaedi, J., Irviani, R., Muslihudin, M., Hidayat, S., Maseleno, A., Gumanti, M., \& Fauzi, A. N. (2018). Application program learning based on android for students experiences. International Journal of Engineering and Technology (UAE), 7(2.27), 194-198.

Kartimi, K., \& Liliasari, L. (2012). Pengembangan alat ukur berpikir kritis pada konsep termokimia untuk siswa SMA Peringkat atas dan menengah. Jurnal Pendidikan IPA Indonesia, 1(1), 122852.

Khasanah, A. N., Widoretno, S., \& Sajidan, S. (2017). Effectiveness of Critical Thinking IndicatorBased Module in Empowering Student's Learning Outcome in Respiratory System Study Material. Jurnal Pendidikan IPA Indonesia, 6(1), 120425.

Lee, S., Kang, E., \& Kim, H. B. (2015). Exploring impact of students' learning approach on col- 
laborative group modeling of blood circulation. Journal of Science Education and Technology, 24(2), 234-255.

Mardikaningtyas, D. A., Ibrohim, I., \& Suarsini, E. (2016). Pengembangan Pembelajaran Pencemaran Lingkungan Berbasis Penelitian Fitoremediasi untuk Menunjang Keterampilan I1miah, Sikap Peduli Lingkungan dan Motivasi Mahasiswa pada Matakuliah Dasar-Dasar Ilmu Lingkungan. Jurnal Pendidikan: Teori, Penelitian, dan Pengembangan, 1(3), 499-506.

Maulana, H., \& Sulistyoningrum. (2018). Implementation Mirror Technique 3D Objects for Interactive Learning Media "Circulatory System" Virtual Reality-Based. Journal of Physics: Conference Series, 1364, 012036.

Morel, M., Peruzzo, N., Juele, A. R., \& Amarelle, V. (2019). Comics as an Educational Resource to Teach Microbiology in the Classroom. Journal of microbiology \& biology education, 20(1), 1-4.

Mutakinati, L., Anwari, I., \& Yoshisuke, K. (2018). Analysis of students' critical thinking skill of middle school through STEM education project-based learning. Jurnal Pendidikan IPA Indonesia, 7(1), 54-65.

Nhat, H. T., Lien, N. T., Tinh, N. T., Hang, N. V. T., \& Trang, N. T. (2018). The Development of Critical Thinking for Students in Vietnamese Schools: From Policies to Practices. American Journal of Educational Research, 6(5), 431-435.

Özdemir, E. (2017). Humor in Elementary Science: Development and Evaluation of Comic Strips about Sound. International Electronic Journal of Elementary Education, 9(4), 837-850.

Prawita, W., Prayitno, B. A., \& Sugiyarto. (2019). Effectiveness of generative learning-based biology module to improve the analytical thinking skills of the students with high and low reading motivation. International Journal of Instruction, 12(1), 1459-1476.

Pujiasih, P., Isnaeni, W., \& Ridlo, S. (2021). Androidbased e-booklet development to train students' critical thinking and attitude of caring for environment. Journal of Innovative Science Education, 10(1), 95-101.

Purnami, W., Sarwanto, S., Suranto, S., Suyanti, R., \& Mocerino, M. (2021). Investigation of Science Technology Ecocultural Society (STEcS) Model to Enhance Eco Critical Thinking Skills. Journal of Innovation in Educational and Cultural Research, 2(2), 77-85.

Puspita, I., Kaniawati, I., \& Suwarma, R. (2017). Analysis of critical thinking skills on the topic static fluid. Journal of Physics: Conference Series, 895, 012100.

Puspitasari, E. D. T., Surjono, H. D., \& Minghat, A. D. (2018). Utilizing web-based learning as $21^{\text {st }}$ century learning media for vocational education. International Journal of Enginering \& Technology, 7(4.33), 157-160.

Putri, M. A., \& Prodjosantoso, A. K. (2020). Improving Critical Thinking Skills and Scientific Attitudes by Using Comic. Psychology, Evaluation, and Technology in Educational Research, 2(2), 6980.

Rohmadi, M., \& Nasucha, Y. (2015). Dasar-dasar penelitian bahasa, sastra, dan pengajaran. Surakarta: Pustaka Briliant.

Sari, R., Perdana, R., Riwayani, Jumadi, Wilujeng, I., \& Kuswanto, H. (2019). The implementation of problem-based learning model woth online simulation to enhance the student's analytical thinking skill in learning physics. Journal of Physics: Conference Series, 1233, 012030.

Seventika, S. Y., Sukestiyarno, Y. L., \& Mariani, S. (2018, March). Critical thinking analysis based on Facione (2015)-Angelo (1995) logical mathematics material of vocational high school (VHS). In Journal of Physics: Conference Series (Vol. 983, No. 1, p. 012067). IOP Publishing.

Styers, M. L., Van Zandt, P. A., \& Hayden, K. L. (2018). Active Learning in Flipped Life Science Courses Promotes Development of Critical Thinking Skills. CBE life sciences education, 17(3), ar39.

Sudarsana, I. K., Nakayanti, A. R., Sapta, S., Haimah, Satria, E., Saddhono, K., GS, D. A., Putut, E., Helda, T., \& Mursalin, M. (2019). Technology application in education and learning process. Journal of Physics: Conference Series, 1363, 012061.

Sugiyono. (2015). Metode penelitian pendidikan. Bandung: Alfabeta.

Sujatmiko, Y. A., Isnaeni, W., Ridlo, S., \& Saptono, S. (2021). The development of andro-webcomic media based on problem-based learning to improve analytical thinking ability and scientific attitude. In Journal of Physics: Conference Series (Vol. 1918, No. 5, p. 052023). IOP Publishing.

Sukenda, Anjani, M., \& Yustim, B. (2019). Learning Media for Biology Subject Based on Multimedia in Junior High School Level. Universal Journal of Educational Research, 7(4A), 43-51.

Sung, Y. T., Chang, K. E., \& Liu, T. C. (2016). The Effects of Integrating mobile Devices with Teaching and Learning on Students' Learning Performance: A Meta-Analysis and Research Synthesis. Computers \& Education, 94, 252-275.

Surjanti, J., Seno, D. N., Hadi, H. K.., Maroah, S., Siswanti, Y., Muafi., \& Isfianadewi, D. (2018). The role of m-learning on effective learning media in higher education. International Journal of Civil Engineering and Technology, 9(4), 77-85.

Thomas, T. (2011). Developing First Year Student's Critical Thinking Skills. Asian Social Science, 7(4), 26-35.

Wiguna, D., Irwansyah, F. S., Windayani, N., Aulawi, H., \& Ramdhani, M. A. (2019). Development of android-based chemistry learning media oriented towards generic science skills. Journal of Physics: Conference Series, 1157, 042047.

Williamson, B., Eynon, R., \& Potter, J. (2020). Pandemic Politics, Pedagogies and Practices: Digital Technologies and Distance Education during the Coronavirus Emergency. Learning, Media and Technology, 45(2), 107-114. 